\title{
Karakteristik Kolestasis Intrahepatik dengan Infeksi Saluran Kemih
}

\author{
Elisabeth Hutapea, Julfina Bisanto, Damayanti R. Sjarif, Partini P. Trihono \\ Departemen Ilmu Kesehatan Anak Fakultas Kedokteran Universitas Indonesia RS Dr. Cipto Mangunku- \\ sumo, Jakarta
}

\begin{abstract}
Latar belakang. Kolestasis intrahepatik (KI) merupakan salah satu kasus pada bayi yang sering ditemukan. Tata laksana seringkali sulit karena KI sulit menentukan etiologi yang sangat beragam dan memerlukan berbagai pemeriksaan penunjang. Infeksi saluran kemih (ISK) merupakan salah satu infeksi ekstrahepatik tersering yang menyebabkan KI pada bayi.

Tujuan. Mengetahui karakteristik pasien KI dengan ISK.

Metode. Desain penelitian adalah deskriptif retrospektif dari data pasien KI yang berobat ke RS Cipto Mangunkusumo dalam kurun waktu Januari 2001 hingga Desember 2006.

Hasil. Proporsi ISK didapatkan pada 56 (77\%) diantara 73 pasien KI berusia 0-12 bulan di RSCM yang dilakukan biakan urin. Kolestasis intrahepatik dengan ISK lebih sering pada laki-laki (79\%), cukup bulan (80\%), dan usia tersering $0-3$ bulan (75\%). Tinja umumnya berwarna kuning (41\%) atau dempul fluktuatif (52\%). Hepatomegali ditemukan pada $37 \%$ pasien. Gejala klinis tersering adalah ikterik asimptomatik (71\%). Rerata kadar bilirubin direk didapatkan $6,6 \mathrm{mg} / \mathrm{dL}(1,8-15,8)$, kadar bilirubin indirek 1,5 mg/dL (0,2-6,9), kadar AST 134 U/L (23-660), kadar ALT 114 U/L (14-588), kadar GGT 159 U/L (14-1039) dan albumin 3,7 g/dL (2,3-5,0). Anemia didapatkan pada 11 (20\%) pasien dan leukositosis pada 7 (12\%) pasien. Nilai PT memanjang terdapat pada $10(22 \%)$ pasien. Urinalisis pada $75 \%$ pasien dalam batas normal. $E$. coli merupakan kuman penyebab ISK tersering (52\%).

Kesimpulan. Proporsi ISK pada KI cukup tinggi (77\%). Kejadian ISK pada KI terutama ditemukan pada bayi laki-laki, cukup bulan dan berusia 0-3 bulan. Tidak ditemukan gejala klinis spesifik pada KI dengan ISK. Proporsi tinja berwarna dempul, hepatomegali, anemia, nilai PT memanjang, serta rerata kadar ALT dan AST, meningkat dengan bertambah lamanya kolestasis. Umumnya urinalisis dalam batas normal, sehingga pemeriksaan biakan urin harus dilakukan pada setiap pasien KI untuk mencari kemungkinan ISK. (Sari Pediatri 2008;10(6):71-6).
\end{abstract}

Kata kunci: kolestasis intrahepatik, infeksi saluran kemih

Alamat Korespondensi:

Dr. Julfina Bisanto, Sp.A(K). Divisi Gastrohepatologi. Departemen Ilmu Kesehatan Anak Fakultas Kedokteran Universitas Indonesia Jl. Salemba no. 6, Jakarta 10430. Telepon: 021-3915665. Fax. 021-3915712.

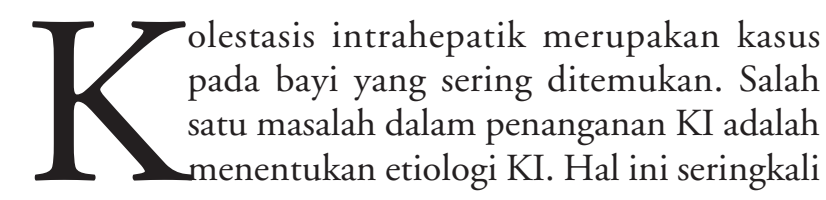


sulit karena etiologinya sangat beragam, sehingga memerlukan berbagai pemeriksaan penunjang. ${ }^{1-}$ ${ }^{4}$ Infeksi saluran kemih (ISK) merupakan infeksi ekstrahepatik yang paling sering menyebabkan KI pada bayi. ${ }^{5,6}$ Sitokin (TNF $\alpha$ ) yang dilepaskan pada keadaan infeksi menghambat fungsi protein transporter pada membran basolateral hepatosit dan kanalikulus (Ntcp, Oatp, Mrp2 dan Bsep), sehingga menyebabkan KI..$^{6-15}$ Infeksi saluran kemih merupakan salah satu etiologi KI yang bersifat potentially treatable, sehingga diagnosis dini penting dilakukan. ${ }^{5}$

\section{Metode}

Penelitian ini merupakan penelitian deskriptif retrospektif dilakukan di Departemn Ilmu Kesehatan Anak RS Dr. Cipto Mangunkusumo Jakarta. Populasi terjangkau adalah bayi berusia $0-12$ bulan dengan KI yang berobat ke RSCM dalam kurun waktu Januari 2001 hingga Desember 2006. Kriteria inklusi adalah usia 0-12 bulan, lama ikterik kurang dari 6 bulan, yang mempunyai data, hasil pemeriksaan bilirubin direk/indirek, AST, ALT, GGT, USG hati dan saluran empedu, urinalisis serta biakan urin tercantum lengkap dalam rekam medis. Pasien tidak diikutsertakan bila terdapat infeksi kongenital, kelainan metabolik, kelainan genetik dan sepsis.

\section{Hasil}

Selama kurun waktu 6 tahun (Januari 2001 hingga Desember 2006) didapatkan 188 pasien KI. Diantara 188 pasien KI, terdapat 87 pasien yang memenuhi kriteria inklusi, namun 14 pasien yang dieksklusi, sehingga 73 pasien yang menjadi subjek penelitian.

Biakan urin didapatkan pada $56(77 \%)$ diantara 73 pasien. Pada Tabel 1 tertera KI dengan ISK lebih sering pada usia $0-3$ bulan (75\%), laki-laki (79\%) dan bayi lahir cukup bulan (80\%). Tinja umumnya berwarna kuning (41\%) atau dempul fluktuatif (52\%). Sedangkan hepatomegali ditemukan pada $37 \%$ pasien. Tabel 2 memperlihatkan proporsi tinja berwarna kuning berkurang dengan bertambah lamanya KI, sebaliknya proporsi tinja berwarna dempul cenderung meningkat dengan bertambah lamanya KI. Gejala klinis tersering adalah ikterik asimptomatik (71\%) dan demam hanya ditemukan pada $8(14 \%)$ pasien.
Tabel 1. Karakteristik pasien kolestasis intrahepatik dengan ISK

\begin{tabular}{|c|c|c|}
\hline Karakteristik & $\begin{array}{c}\text { Jumlah } \\
(\mathrm{n}=56)\end{array}$ & Persentase (\%) \\
\hline \multicolumn{3}{|l|}{ Usia (bulan) } \\
\hline - $0-3$ & 42 & 75 \\
\hline - $>3-6$ & 10 & 18 \\
\hline - $>6-9$ & 4 & 7 \\
\hline$\cdot>9-12$ & 0 & 0 \\
\hline \multicolumn{3}{|l|}{ Jenis kelamin (bulan) } \\
\hline - laki-laki & 44 & 79 \\
\hline • perempuan & 12 & 21 \\
\hline \multicolumn{3}{|l|}{ Lama kolestasis (bulan) } \\
\hline$\bullet<2$ & 33 & 59 \\
\hline - $2-4$ & 19 & 34 \\
\hline$\cdot>4-6$ & 4 & 7 \\
\hline \multicolumn{3}{|l|}{ Usia gestasi (minggu) } \\
\hline - $\geq 37$ & 45 & 80 \\
\hline$\bullet<37$ & 11 & 20 \\
\hline Berat lahir (gram)* & $2906( \pm 654)$ & \\
\hline \multicolumn{3}{|l|}{ Warna tinja } \\
\hline • kuning & 23 & 41 \\
\hline - dempul fluktuatif & 29 & 52 \\
\hline - dempul persisten & 4 & 7 \\
\hline \multicolumn{3}{|l|}{ Hepatomegali } \\
\hline - ya & 21 & 37 \\
\hline - tidak & 35 & 63 \\
\hline
\end{tabular}

Keterangan: ${ }^{*}$ : nilai rerata (simpang baku)

Tabel 2. Sebaran warna tinja, hepatomegali dan gejala klinis pasien kolestasis intrahepatik dengan ISK berdasarkan lama kolestasis

\begin{tabular}{|c|c|c|c|c|}
\hline \multirow[b]{2}{*}{ Karakteristik } & \multicolumn{3}{|c|}{ Lama kolestasis } & \multirow[b]{2}{*}{$\begin{array}{l}\text { Total } \\
(\%)\end{array}$} \\
\hline & $\begin{array}{c}<2 \text { bulan } \\
(\mathrm{n}=33)\end{array}$ & $\begin{array}{c}2-4 \\
\text { bulan } \\
(\mathrm{n}=19)\end{array}$ & $\begin{array}{l}>4-6 \\
\text { bulan } \\
(\mathrm{n}=4)\end{array}$ & \\
\hline \multicolumn{5}{|l|}{ Warna tinja } \\
\hline - kuning & 17 & 6 & 0 & $23(41)$ \\
\hline - dempul fluktuatif & 15 & 11 & 3 & $29(52)$ \\
\hline - dempul persisten & 1 & 2 & 1 & $4(7)$ \\
\hline \multicolumn{5}{|l|}{ Hepatomegali } \\
\hline - ya & 9 & 9 & 3 & $21(37)$ \\
\hline - tidak & 24 & 10 & 1 & $35(63)$ \\
\hline \multicolumn{5}{|l|}{ Gejala klinis* } \\
\hline - ikterik asimptomatik & 21 & 16 & 3 & $40(71)$ \\
\hline - demam & 5 & 3 & 0 & $8(14)$ \\
\hline - gagal tumbuh & 5 & 0 & 1 & $6(11)$ \\
\hline - diare & 3 & 1 & 0 & $4(7)$ \\
\hline
\end{tabular}

*Pada 1 pasien dapat ditemukan $>1$ gejala 
Rerata kadar bilirubin direk dan indirek hampir sama pada pasien dengan lama kolestasis yang berbeda. Rerata kadar AST dan ALT cenderung meningkat dengan bertambah lamanya kolestasis. Kadar GGT bervariasi luas (14-1039 U/L) dan kadar albumin dalam batas normal (Tabel 3).

Anemia didapatkan pada 11 (20\%) pasien dan leukositosis 7 (12\%) pasien. Proporsi anemia cenderung meningkat dengan bertambah lamanya kolestasis (Tabel 4). Sedangkan kadar PT memanjang terdapat pada $10(22 \%)$ pasien dan proporsi meningkat dengan bertambah lamanya kolestasis (Tabel 4).

Pada Tabel 5 dan 6 tertera urinalisis pada $75 \%$ pasien dalam batas normal, leukosituria ditemukan hanya pada 7 (12\%) pasien dan E. coli merupakan kuman penyebab ISK tersering (52\%).

\section{Pembahasan}

Proporsi ISK pada KI yang ditemukan ini hampir sama dengan penelitian Oswari dkk., ${ }^{16}$ yaitu 24/34 (70\%). Sedangkan penelitian Karim dan $\mathrm{Kamal}^{3}$ menemukan ISK pada 5 (12\%) dari 42 pasien KI. Perbedaan hasil ini terjadi karena pada penelitian Karim dan Kamal pemeriksaan biakan urin dilakukan pada seluruh pasien KI. Usia 0-3 bulan dan laki-laki (79\%) lebih sering mengalami KI dengan ISK seperti juga dilaporkan oleh Seeler dan Hahn ${ }^{17}$ maupun $\mathrm{Ng}$ dan Rawstron. ${ }^{18}$

Insidens refluks dan kelainan anatomi saluran kemih yang lebih tinggi pada bayi laki-laki, dilaporkan sebagai penyebab kecenderungan bayi laki-laki mengalami ISK. Namun hal tersebut masih

Tabel 3. Rerata kadar bilirubin, AST, ALT, GGT dan albumin pasien kolestasis intrahepatik dengan ISK dan berdasarkan lama kolestasis

\begin{tabular}{lcccc}
\hline \multirow{2}{*}{ Hasil laboratorium } & Rerata secara & \multicolumn{2}{c}{ Rerata berdasarkan lama kolestasis } \\
\cline { 3 - 5 } & keseluruhan & $\begin{array}{c}<2 \text { bulan } \\
(\mathrm{n}=33)\end{array}$ & $\begin{array}{c}2-4 \text { bulan } \\
(\mathrm{n}=19)\end{array}$ & $\begin{array}{c}>4-6 \text { bulan } \\
(\mathrm{n}=4)\end{array}$ \\
\hline Bilirubin direk (mg/dL) & $6,6(1,8-15,8)$ & $6,7(1,8-15,8)$ & $6,8(2,2-13,4)$ & $6,2(5,2-12,9)$ \\
Bilirubin indirek (mg/dL) & $1,5(0,2-6,9)$ & $1,8(0,4-6,9)$ & $1,3(0,6-5,9)$ & $1,2(0,2-5,8)$ \\
AST (U/L) & $134(23-660)$ & $127(23-660)$ & $142(66-488)$ & $310(76-613)$ \\
ALT (U/L) & $114(14-588)$ & $106(14-588)$ & $122(18-340)$ & $288(27-364)$ \\
GGT (U/L) & $159(14-1039)$ & $147(32-895)$ & $179(74-1039)$ & $143(14-411)$ \\
Albumin (g/dL) & $3,7(2,3-5,0)$ & $3,6(2,7-5,0)$ & $3,8(2,3-4,2)$ & $3,9(3,4-4,3)$ \\
\hline
\end{tabular}

Keterangan : nilai median (nilai terendah-nilai tertinggi)

Tabel 4. Profil gambaran pemeriksaan darah pasien kolestasis intrahepatik dengan ISK berdasarkan lama kolestasis

\begin{tabular}{lcccc}
\hline \multirow{2}{*}{ Profil darah tepi } & \multicolumn{3}{c}{ Lama kolestasis } & \\
\cline { 2 - 4 } & $\begin{array}{c}<\text { bulan } \\
(\mathrm{n}=33)\end{array}$ & $\begin{array}{c}2-4 \text { bulan } \\
(\mathrm{n}=19)\end{array}$ & $\begin{array}{c}>4-6 \text { bulan } \\
(\mathrm{n}=4)\end{array}$ & Total $(\%)$ \\
\hline Normal & 24 & 14 & 2 & $40(71)$ \\
Abnormal & 9 & 5 & 2 & $16(29)$ \\
- Anemia & 4 & 5 & 2 & $11(20)$ \\
- Leukositosis & 6 & 0 & 1 & $7(12)$ \\
- Trombositopenia & 0 & 0 & 0 & 0 \\
Nilai PT & & Lama kolestasis & & \\
\cline { 2 - 4 } & $<2$ bulan & $2-4$ bulan & $>4-6$ bulan & \\
- PT normal & $(\mathrm{n}=28)$ & 10 & 1 & $35(78)$ \\
- PT memanjang & 24 & 4 & 2 & $10(22)$ \\
\hline
\end{tabular}


Tabel 5. Profil urinalisis pasien kolestasis intrahepatik dengan ISK

\begin{tabular}{lcc}
\hline \multicolumn{1}{c}{ Urinalisis } & $\begin{array}{c}\text { Jumlah } \\
(\mathrm{n}=56)\end{array}$ & $\begin{array}{c}\text { Persentase } \\
(\%)\end{array}$ \\
\hline Normal & 42 & 75 \\
Abnormal & 14 & 25 \\
- Leukosituria & 7 & 12 \\
- Leukosit esterase positif & 7 & 12 \\
- Bakteriuria & 4 & 7 \\
- Hematuria & 1 & 2 \\
- Uji nitrit positif & 0 & 0 \\
\hline
\end{tabular}

Tabel 6. Sebaran kuman penyebab ISK berdasarkan usia

\begin{tabular}{lcccc}
\hline \multirow{2}{*}{ Kuman patogen } & \multicolumn{3}{c}{ Usia (bulan) } & \\
\cline { 2 - 4 } & $\begin{array}{c}0-3 \\
(\mathrm{n}=42)\end{array}$ & $\begin{array}{c}>3-6 \\
(\mathrm{n}=10)\end{array}$ & $\begin{array}{c}>6-9 \\
(\mathrm{n}=4)\end{array}$ & $\begin{array}{c}\text { Total } \\
(\%)\end{array}$ \\
\hline E. coli & 20 & 7 & 2 & $29(52)$ \\
Enterobacter aerogenes & 13 & 1 & 1 & $15(27)$ \\
Staphylococcus epidermidis & 3 & 2 & 0 & $5(9)$ \\
Klebsiela pneumonia & 3 & 0 & 1 & $2(7)$ \\
Proteus & 2 & 0 & 0 & $1(2)$ \\
Serratia & 1 & 0 & 0 & \\
\hline
\end{tabular}

kontroversi mengingat beberapa peneliti lain tidak mendapatkan perbedaan insidens refluks dan kelainan anatomi saluran kemih antara bayi laki-laki dengan perempuan. ${ }^{20}$ Kami jumpai kelainan anatomi pada 3 dari 21 pasien yang dilakukan USG ginjal dan saluran kemih, dan seluruhnya adalah laki-laki.

Proporsi pasien lahir kurang bulan 20\%, lebih tinggi dibandingkan penelitian Seeler dan Hahn (9\%), ${ }^{17}$ maupun $\mathrm{Ng}$ dan Rawstron (0\%), ${ }^{18}$ sehingga masih mungkin mempengaruhi tingginya proporsi kejadian KI dengan ISK pada penelitian kami. Mekanisme sistem protein transporter empedu yang belum sempurna pada bayi kurang bulan, sehingga terdapat kecenderungan untuk terjadinya KI pada keadaan infeksi lebih tinggi. ${ }^{5}$

Warna tinja pada pasien KI dengan ISK umumnya kuning (41\%) atau dempul fluktuatif (52\%), tidak berbeda dengan warna tinja pasien KI pada umumnya. ${ }^{1}$ Pada Tabel 2 tampak proporsi tinja berwarna kuning berkurang dengan bertambah lamanya KI. Sebaliknya jumlah bayi yang mempunyai tinja berwarna dempul cenderung meningkat dengan bertambah lamanya KI yang diderita. Pada fase awal umumnya obstruksi bilier intrahepatik parsial ringan, selanjutnya dengan bertambah lamanya kolestasis obstruksi semakin berat sehingga jumlah bayi yang mempunyai tinja berwarna dempul makin banyak. ${ }^{5,19}$

Proporsi hepatomegali cenderung meningkat dengan bertambah lamanya kolestasis (Tabel 2). Meningkatnya inflamasi sel hati pada kolestasis yang berlangsung lebih lama diduga menjadi penyebab. Ikterik asimtomatik (71\%) lebih sering ditemukan dan demam ditemukan pada $14 \%$ pasien, memperlihatkan bahwa pada usia 0-3 bulan gejala ISK tidak spesifik. $^{21}$

Peningkatan bilirubin direk lebih tinggi didapatkan pada infeksi berat (bakteremia), akibat terjadinya hambatan fungsi sistem protein transporter yang lebih berat. Bakteremia pada penelitian Seeler dan Hahn adalah 7 dari 11 pasien, ${ }^{17}$ dan pada penelitian Ng dan Rawstron adalah 4 dari 6 pasien. ${ }^{18}$ Sedangkan bilirubin indirek pada penelitian kami 1,5 mg/dL (Tabel 3), Seeler dan Hahn 11,9 mg/dL, ${ }^{17}$ dan $\mathrm{Ng}$ dan Rawstron $4,7 \mathrm{mg} / \mathrm{dL} .{ }^{18}$ E. coli sebagai kuman patogen ISK yang lebih sering ditemukan, Seeler dan Hahn (82\%), ${ }^{17}$ maupun penelitian $\mathrm{Ng}$ dan Rawstron (83\%), ${ }^{18}$ dan penelitian kami (52\%), kemungkinan disebabkan oleh hemolisis eritrosit dilaporkan sering terjadi pada ISK yang disebabkan E. coli dibandingkan kuman lain. ${ }^{19}$

Menurut Ng dan Rawstron, ${ }^{18}$ kolestasis bukan satu-satunya kelainan hepatobilier yang terjadi pada ISK, tetapi gangguan hepatoselular turut pula terjadi, karena kuman gram negatif diduga menimbulkan hepatitis toksik. ${ }^{19}$ Pada Tabel 3 tampak rerata kadar AST dan ALT cenderung meningkat dengan bertambah lamanya kolestasis, sebagai akibat kerusakan hati bertambah seiring dengan bertambah lamanya kolestasis dan ISK. Kadar GGT sangat bervariasi luas sehingga tidak dapat digunakan untuk membedakan kolestasis ekstrahepatik, terutama atresia bilier dengan hepatitis neonatal. Kadar GGT bervariasi luas (14-1039 U/L), rerata berkisar 5 kali nilai normal (159 U/L), tidak berbeda dengan pasien KI pada umumnya. ${ }^{1}$ Sedangkan rerata kadar albumin dalam batas normal, ${ }^{18}$ karena pasien dengan dugaan penyakit hati kronik (lama kolestasis lebih dari 6 bulan) dieksklusi dari penelitian ini, sehingga umumnya fungsi sintesis hati masih baik.

Nilai PT yang memanjang didapatkan pada 10 (22\%) pasien dan cenderung meningkat dengan bertambah lamanya kolestasis, akibat defisiensi vitamin 
Kyang terjadi pada kolestasis yang berlangsung lama. ${ }^{19}$ Nilai PT yang memanjang ini bukan disebabkan oleh gangguan fungsi sintesis parenkim hati, yang terlihat dari rerata albumin yang masih dalam batas normal.

Empat puluh (71\%) pasien mempunyai hasil pemeriksaan darah normal dan anemia pada 20\% pasien, Seeler dan Hahn (6/11), ${ }^{17}$ maupun $\mathrm{Ng}$ dan Rawstron (4/6), ${ }^{18}$ melaporkan anemia akibat infeksi E. coli sebagai penyebab ISK. Anemia lebih sering didapatkan pada ISK yang disebabkan oleh kuman E.coli (7/11) daripada kuman lain selain E.coli (4/11), karena pada infeksi E.coli terjadi pengelepasan $\alpha$ hemolysin. ${ }^{18}$ Anemia lebih sering ditemukan pada kolestasis yang berlangsung lebih lama karena komplikasi anemia hemolitik akibat defisiensi vitamin E. ${ }^{19}$

Leukosituria pada ISK memiliki sensitivitas yang bervariasi antara $32-100 \%$, dan bukan merupakan pemeriksaan yang reliable untuk membedakan ISK dan bukan ISK. ${ }^{24}$ Spesimen urin yang segar (kurang dari 30 menit) sangat dibutuhkan untuk meningkatkan sensitivitas tersebut. ${ }^{25}$ Sensitivitas urinalisis pada bayi berusia kurang dari 90 hari lebih rendah dibandingkan bayi berusia lebih dari 90 hari, karena respons inflamasi yang lebih rendah dan frekuensi berkemih yang lebih sering pada kelompok usia ini. ${ }^{27}$ Sebagian besar $(75 \%)$ pasien berusia kurang dari 90 hari, sehingga hasil urinalisis yang mendukung ISK hanya didapatkan pada 14 (25\%) pasien.

Kuman penyebab ISK tersering adalah E. Coli. Friedman $\mathrm{dkk},{ }^{26}$ mendapatkan bahwa pasien ISK yang disebabkan kuman lain selain $E$. coli, berusia lebih muda. Mengingat ISK pada penelitian ini dapat merupakan etiologi atau hanya koinsidens, maka usia saat kolestasis terjadi, belum tentu merupakan usia saat terjadinya ISK. Sebaliknya usia saat datang berobat ke RSCM belum tentu merupakan usia saat pasien mengalami ISK. Oleh karena itu tidak dapat dipastikan sebaran kuman berdasarkan kelompok usia pada penelitian ini.

Pada 21 pasien yang dilakukan pemeriksaan USG ginjal dan saluran kemih, didapatkan kelainan anatomi pada 3 pasien, kuman penyebab ISK pada 2 dari 3 pasien adalah kuman lain selain E. coli. Menurut Friedman $\mathrm{dkk},{ }^{26}$ pasien ISK yang disebabkan kuman lain selain $E$. coli cenderung memiliki kelainan anatomi saluran kemih dibandingkan ISK yang disebabkan kuman E.coli.

\section{Kesimpulan}

Proporsi ISK 77\% pada pasien KI yang dilakukan biakan urin. Kejadian ISK pada KI terutama ditemukan pada bayi laki-laki, cukup bulan, dan berusia 0-3 bulan. Gambaran pasien KI dengan ISK hampir sama dengan pasien KI pada umumnya, kecuali rerata kadar AST dan ALT. Rerata kadar AST dan ALT berkisar 5 kali nilai normal, sedangkan pada pasien KI pada umumnya berkisar 10 kali nilai normal. Proporsi tinja berwarna dempul, hepatomegali, anemia, nilai PT memanjang, serta rerata kadar ALT dan AST, meningkat dengan bertambah lamanya kolestasis. Umumnya urinalisis dalam batas normal, sehingga pemeriksaan biakan urin harus dilakukan untuk mencari kemungkinan ISK pada pasien KI.

\section{Daftar Pustaka}

1. Bisanto J. Kolestasis pada bayi. Dalam: Trihono PP, Purnamawati S, Syarif DR, Hegar B, Gunardi H, Oswari $\mathrm{H}$, dkk, penyunting. Hot Topics in Pediatrics II. Jakarta: Balai Penerbit FKUI; 2002.h.84-99.

2. NASPGHAN. Guideline for the evaluation of cholestatic jaundice in infants: recommendations of the North American Society for Pediatric Gastroenterology, Hepatology and Nutrition. J Pediatr Gastroenterol Nutr 2004;39:115-28.

3. Karim ASMB, Kamal M. Cholestatic jaundice during infancy: experience at a tertiary-care center in Bangladesh. Indian J Gastroenterol 2005;24:52-4.

4. Motala C, Ireland JD, Hill ID, Bowie MD. Cholestatic disorders of infancy-aetiology and outcome. J Trop Pediatr 1990;36:218-22. (abstrak).

5. Mowat AP. Hepatitis and cholestasis in infancy: intrahepatic disorders. Dalam: Mowat AP, penyunting. Liver disorders in childhood. Edisi ke-3. Oxford: Butterworth-Heinemann;1994.h.43-78.

6. Trauner M, Fickert P, Stauber R. Inflammation-induced cholestasis. J Gastroenterol Hepatol 1999;14:946-59.

7. Rodriguez-Garay EA. Cholestasis: human disease and experimental animal models. Ann Hepatol 2003;2:150-8.

8. Phillips MJ. Mechanism and morphology of cholestasis. Dalam: Suchy FJ, Sokol RJ, Balistreri WF, penyunting. Liver disease in children. Philadelphia: Lippincott Williams \& Wilkins; 2001.h.129-39.

9. Emerick KM, Whitington PF. Molecular basis of neonatal cholestasis. Pediatr Clin N Am 2002;49:221-35. 
10. Trauner M, Meier PJ, Boyer JL. Molecular pathogenesis of cholestasis. NEJM 1998; 339:1217-27.

11. Arrese M, Accatino L. From blood to bile: recent advances in hepatobiliary transport. Ann Hepatol 2002;1:64-71.

12. Elferink RO. Cholestasis. Gut 2003;52:ii42-8.

13. Whiting JF, Green RM, Rosenbluth AB, Gollan JL. Tumor necrosis factor-alpha decreases hepatocyte bile salt uptake and mediates endotoxin-induced cholestasis. Hepatology 1995;22:1273-8.

14. Vos TA, Hooiveld GJEJ, Koning H, Childs S, Meijer DKF, Moshage $\mathrm{H}$, dkk. Up-regulation of the multidrug resistance genes, Mrp1 and Mdr 1b, and down regulation of the organic anion transporter, Mrp 2 and the bile salt transporter, Spgp in endotoxemic rat liver. Hepatology 1998;28:1637-44.

15. Geier A, Dietrich CG, Voight S, Kim SK, Gerloff T, Kullak-Ublick GA, et al. Effect of proinflammatory cytokines on rat organic anion transporters during toxic liver injury and cholestasis. Hepatology 2003;38:34554.

16. Oswari H, Harijadi, Bisanto J, Purnamawati SP. Infeksi saluran kemih sebagai penyebab kolestasis intrahepatik. Sari Pediatri 2005;6:166-71.

17. Seeler RA, Hahn K. Jaundice in urinary tract infection in infancy. Amer J Dis Child 1969;118:553-8.

18. $\mathrm{Ng} \mathrm{SH}$, Rawstron JR. Urinary tract infections presenting with jaundice. Arch Dis Child 1971;46:173-6.

19. Suchy FJ. Approach to the infant with cholestasis. Dalam: Suchy FJ, Sokol RJ, Balistreri WF, penyunting. Liver disease in children. Edisi ke-2. Philadelphia: Lippincott Williams \& Wilkins; 2001.h.187-94.

20. Kanellopoulos TA, Salakos C, Spiliopoulou I, Ellina A, Nikolakopoulou NM, Papanastasiou DA. First urinary tract infection in neonates, infants and young children: a comparative study. Pediatr Nephrol 2006;21:1131-7.

21. Chang SL, Shortliffe LD. Pediatric urinary tract infections. Pediatr Clin N Am 2006;53:379-400.

22. Nadi HM, Shalan YAF, Al-Qatan HYA, Alotaibi S. Urinary tract infection in boys less than five years of age: a general pediatric perspective. Kuw Med J 2006;38:2205.

23. Saleh SI, Tuhmaz MM, Sarkhouh MY, El-Ghawabi. Urinary tract infection in infants and children in Al-Jahra Area, Kuwait: an overview. Kuw Med J 2003;35:31-5.

24. Lambert $H$, Coulthard M. The child with urinary tract infection. Dalam: Webb NJA, Postlethwaite RJ, penyunting. Clinical paediatric nephrology. Edisi ke-3. Oxford: Oxford University Press; 2003.h.97-225.

25. Simerville JA, Maxted WC, Pahira JJ. Urinalysis: a comprehensive review. Am Fam Physician 2005;71: 1153-62.

26. Friedman S, Reif S, Assia A, Levy I. Clinical and laboratory characteristics of non-E coli urinary tract infections. Arch Dis Child 2006;91:845-6.

27. McGillivray D, Mok E, Mulrooney E, Kramer MS. A head-to-head comparison: "clean-void" bag versus catheter urinalysis in the diagnosis of urinary tract infection in young children. J Pediatr 2005;147:451-6. 